\title{
Antibiosis levels of common bean genotypes toward Zabrotes subfasciatus (Boheman) (Coleoptera: Bruchidae) and its correlation with flavonoids
}

\author{
Wellington Ivo Eduardo a, *, Arlindo Leal Boiça Júnior a , \\ Renato Franco Oliveira de Moraes ${ }^{a}$, Alisson Fernando Chiorato ${ }^{b}$, Bruno Perlatti ${ }^{c}$, \\ Moacir Rossi Forim ${ }^{\mathrm{c}}$ \\ a Universidade Estadual Paulista “Júlio de Mesquita Filho", Departmento de Fitossanidade, Via de Acesso Professor Paulo Donato Castellane, s/n, 14884-900, \\ Jaboticabal, Brazil \\ ${ }^{\mathrm{b}}$ Instituto Agronômico de Campinas, Avenida Barão de Itapura, 1481, 13020-902, Brazil \\ ${ }^{c}$ Universidade Federal de São Carlos, Departmento de Química, Rod. Washington Luiz, Km 235, Pocket Box 676, São Carlos, SP 13.565-905, Brazil
}

\section{A R T I C L E I N F O}

\section{Article history:}

Received 12 August 2015

Received in revised form

13 January 2016

Accepted 30 January 2016

Available online 12 February 2016

\section{Keywords:}

Phaseolus vulgaris

Host plant resistance to insect

Multivariate analysis

Secondary metabolites

Bean weevil

\begin{abstract}
A B S T R A C T
Expression of the antibiosis-resistance category to weevils has been evaluated in several bean genotypes with very promising results. Among the several causes responsible for this resistance category the arcelin protein and trypsin inhibitors stand out. Other mechanisms may be associated with plant resistance to the attack of weevils; however, few studies seek to discover these possible causes. Thus, our research aimed at identifying bean genotypes resistant to Zabrotes subfasciatus, classify them into resistance levels, quantify the content of flavonoids, and correlate it with data obtained from the genotypes. An antibiosis test was performed with beans of 43 genotypes and 40 replications (bean grains) under a completely randomized design. The biological parameters recorded from $Z$. subfasciatus were the periods from egg to larvae, larvae to adult, egg to adult, longevity and life cycle, in addition to egg viability, adults emerged, susceptibility relative index, adult weight, sex ratio, and the dry mass consumed by larvae. The chemical profile of flavonoids from each genotype was assessed by means of LC-MS. Based on the results of the weevil biological parameters and dry mass consumed provided by univariate and multivariate statistical analyses, the bean genotypes were classified into four levels of resistance (antibiosis): highly resistant, moderately resistant, susceptible and highly susceptible. Among the evaluated flavonoids, we could identify isoquercitrin; however, it has no correlation with the expression of resistance. From the results obtained in this work, more studies will be conducted with the genotypes that stood out as resistant, evaluating other resistance categories and defense mechanisms of these materials against the attack of $Z$. subfasciatus and other pests, as well as studies of other important agronomic characteristics aiming at future commercialization of the bean genotypes.
\end{abstract}

() 2016 Elsevier Ltd. All rights reserved.

\section{Introduction}

Plant resistance through antibiosis occurs when the mechanism responsible for the resistance is of chemical nature, negatively affecting insect biology, without interfering with their feeding or

\footnotetext{
* Corresponding author.

E-mail addresses: wellington_ie@hotmail.com (W.I. Eduardo), aboicajr@fcav unesp.br (A.L. Boiça Júnior), renatomoraes2@hotmail.com (R.F.O. Moraes), afchiorato@iac.sp.gov.br (A.F. Chiorato), bperlatti@gmail.com (B. Perlatti), mrforim@ufscar.br (M.R. Forim).
}

oviposition behavior (Boiça Júnior et al., 2015). These negative effects can be acute, usually affecting insect immature forms such as young larvae and eggs, and chronic, which can cause mortality in older larvae or even prevent adult emergence, in addition to debilitating effects, such as reductions in size and weight, increased life cycle, and reduced fertility (Smith, 2005). Antibiosis resistance against weevils has been reported in several bean genotypes, with very promising results. Schoonhoven and Cardona (1983), Baldin and Pereira (2010), Costa et al. (2013), among others, found decreased adult emergence, increased development period, and reduced weight of adults of weevils fed some resistant bean 
genotypes.

Many can be the causes underlying the expression of this resistance category to weevils, highlighting defense proteins. One of the most famous and important defense proteins is arcelin due to its insecticidal properties, and in particular, because of its inhibitory activity on larval development of pests of stored grains (Cardona et al., 1990; Janarthanan and Suresh, 2003; Janarthanan et al., 2008). Resistance in bean genotypes to weevils caused by the presence of arcelin has been found by several authors (Osborn et al., 1988; Wanderley et al., 1997; Barbosa et al., 1999; Miranda et al., 2002; Mazzonetto and Vendramim, 2002). Another important group of defense proteins that has been reported as the cause of antibiosis resistance to weevils are trypsin inhibitors and vicilin globulins (Gatehouse et al., 1979; Macedo et al., 1993; Sales et al., 2005). The $\alpha$-amylase inhibitors found in wild beans can also cause antibiotic effects to weevils by inhibiting the amylase activity in the insect midgut (Suzuki et al., 1993).

Several other chemical mechanisms may be responsible for the expression of antibiosis; however, few studies seek to discover new potential resistance causes in common beans. In a study conducted by Lima et al. (2014), the authors found isoflavonoids in common bean genotypes. These polyphenolic compounds are known to be important components of plant secondary metabolism by reducing the stress caused by abiotic and biotic factors (Taiz and Zeiger, 2009). In addition, isoflavonoids can interfere negatively with insect feeding, oviposition, and development (Harborne and Willians, 2000; Simmonds, 2001, 2003). Associating the presence of determined flavonoids in the expression of plant resistance can be valuable for genetic breeding programs aiming to incorporate these secondary compounds into bean genotypes to obtain commercial cultivars resistant to pest-insect attack.

With genotypes obtained from the genetic breeding program developed by the Agronomic Institute of Campinas (IAC) that associated high-yield disease resistant cultivars (IAC Alvorada, IAC Diplomata and IAC Una) (Iac, 2013) and genotypes with resistance to Z. subfasciatus (Boheman, 1833) (Coleoptera: Bruchidae) (Arc 2, Raz 49, Raz 55 and Raz 59) (Ribeiro-Costa et al., 2007; Baldin and Pereira, 2010; Moraes et al., 2011), to obtain genotypes with weevils resistance and high yields. We carried out an antibiosis test together with analysis of eight flavonoids by means of liquid chromatogram and mass chromatogram with tandem mass spectrometry (LC-MS/MS), to identify genotypes resistant to $Z$. subfasciatus, sort them into resistance levels, and verify possible correlations between flavonoids and genotype data.

\section{Materials and methods}

\subsection{Site of experiment conduction and insect rearing}

The experiment was performed at the College of Agricultural and Veterinary Sciences of the University of São Paulo State (UNESP), Campus in Jaboticabal. Trials were carried out in the Department of Crop Protection at the Laboratory of Plant Resistance to Insects. It was used a acclimatized room at $25 \pm 1{ }^{\circ} \mathrm{C}$, relative humidity of $70 \pm 10 \%$ and $12 \mathrm{~h}$ controlled photophase. The insects were obtained from the laboratory rearing stock, which remain for more than 60 generations in common beans of "Bolinha" cultivar.

\subsection{Development of the bean genotypes tested}

Grains from 43 bean genotypes were used for antibiosis testing. The Agronomic Institute of Campinas (IAC), in Campinas - SP, Brazil, provided the genotypes. These genotypes are derived from parental crosses performed in CIAT (International Center for Tropical Agriculture), located in Calina, Columbia, owning resistance to bean weevil, such as Arcelina 2 (ARC 2) and Raz (abbreviation of resistance to Z. subfasciatus) (Table 1). The genotype used as the susceptibility standard was IAC Una and as the resistance standard was Raz 49 , classified as highly susceptible and highly resistant, respectively, by Costa et al. (2013).

\subsection{Methodology for evaluating antibiosis resistance in bean genotypes}

Testing began by packing grains, 40 of each genotype, into cylindrical plastic containers with $3.9 \mathrm{~cm}$ high and $3.8 \mathrm{~cm}$ in diameter in which 10 couples of $Z$. subfasciatus were released per container. The number of eggs on each grain was observed daily; then the ones containing two eggs were selected, and for grains with more than two eggs, surplus was removed. Eggs were removed with the aid of a stylet, and when there was only one egg on the grain, it was similarly removed and grain was inserted back into a container.

Selected grains were set apart, weighed (obtaining the grain mass before infestation (IGM)) and left into 2-mL Eppendorf ${ }^{B}$ vials for 10 days. Larvae hatching was daily accounted with the aid of a $40 \times$ stereomicroscope to establish the period from egg to larvae hatching (incubation time) and egg viability (\%). Larvae were given as hatched when started feeding, releasing excreta inside eggs, which became whitish, being different from eggs of non-hatched larvae (unviable eggs) that remained translucent.

After 25 days from oviposition onset, grains remained under daily observation to check adult emergence, for further determining the period between larvae hatching and adult emergency (larva to adult), as well as the percentage of larvae that reached adulthood (percentage of adults emerged). They were sexed and confined in 2-mL Eppendorf ${ }^{\mathbb{B}}$ for adult weight ratings $(\mathrm{mg})$, which was measured in an analytical precision balance model AR2140 four digits $(0.0001 \mathrm{~g})$ after $24 \mathrm{~h}$ of emergence, longevity and sex ratio of weevils, using the formula: sex ratio $=$ females number/ total number of weevils emerged.

Based on the number of emerged insects and the average development time we calculated the susceptibility relative index (SRI), adapted from Dobie (1977), using the formula IS $=\left(\operatorname{Ln} \sum x /\right.$ $\mathrm{T}) \times 100 ; \mathrm{SI}=$ susceptibility index, $\mathrm{Ln}=$ logarithm neperian, $\mathrm{x}=$ number of weevils emerged, $\mathrm{T}=$ Average time to development of weevils, this latter calculated by the formula $\mathrm{T}=\sum(\mathrm{xy}) / \sum \mathrm{x}$, begin $\mathrm{y}=$ number of days from egg posture to adult emergence. And finally the susceptibility relative index of (SRI), using the formula SRI $=($ SI of genotype tested $\times 100) /$ SI of standard susceptible genotype (IAC Una).

By the end of adult emergence (five consecutive days without emergence), beans were placed in sealed circulating oven at $60^{\circ} \mathrm{C}$ for $48 \mathrm{~h}$, and again weighed to measure dry mass after infestation (DMI). It was also used an aliquot (non-infested grains) containing 10 grains of each treatment, which remained in the same place and for the same period of experiment conduction.

This aliquot was weighed obtaining the average grain mass before (beginning of infestation) and after drying in oven, similarly to the infested grains, being named as aliquot grain mass (AGM) and aliquot dry mass (ADM), respectively. By these results, it was possible to calculate the consumed dry mass of grains (CDM) by larvae using the following formula: $\mathrm{CDM}=(\mathrm{IGM}-\mathrm{DMI})-(\mathrm{AGM}-\mathrm{ADM})$.

\subsection{Analysis of flavonoids}

Qualitative and quantitative chromatographic analysis of flavonoids were carried out at the Chemistry Department of the Federal University of São Carlos - UFSCar. One-hundred grams of grain of each genotype were singly dried in a sealed circulation oven at 
Table 1

Cultivars and genotypes provided by the Agronomic Institute of Campinas (IAC) to perform resistance tests toward Zabrotes subfasciatus attack.

\begin{tabular}{|c|c|c|c|}
\hline Genotypes (Cultivars) & & Genotypes & Parents \\
\hline Vermelho Graúdo & & 187 & IAC Alvorada $\times$ Raz 55 \\
\hline Arc 2 & & 188 & \\
\hline IAC Alvorada & & 242 & IAC Diplomata $\times$ Raz 49 \\
\hline IAC Diplomata & & 243 & \\
\hline IAC Una & & 244 & \\
\hline Raz 49 & & 245 & \\
\hline Raz 55 & & 246 & \\
\hline Raz 59 & & 247 & \\
\hline Genotypes & Parents & 248 & \\
\hline 173 & IAC Alvorada $\times$ Raz 55 & 249 & \\
\hline 174 & & 280 & Arc $2 \times$ IAC Una \\
\hline 175 & & 281 & \\
\hline 176 & & 282 & \\
\hline 177 & & 283 & \\
\hline 178 & & 284 & \\
\hline 179 & & 359 & RAZ $59 \times$ IAC Diplomata \\
\hline 181 & & 360 & RAZ $59 \times$ IAC Alvorada \\
\hline 182 & & 361 & IAC Diplomata $\times$ Raz 59 \\
\hline 183 & & 362 & \\
\hline 184 & & 363 & IAC Diplomata $\times$ Raz 55 \\
\hline 185 & & 364 & \\
\hline 186 & & 365 & \\
\hline
\end{tabular}

$35^{\circ} \mathrm{C}$ for 5 days, and ground using a knife mill with 25-mesh sieve. Rutin, quercetin, isoquercitrin, daidzin, daidzein, hesperidin, naringin, naringenin and umbelliferone coumarin composed the flavonoids quantified by high-performance liquid chromatography coupled to tandem mass spectrometry (HPLC-MS/MS). These flavonoids were found either in bean genotypes or were assessed as possible causes of the expression of plant resistance or adverse effects to pests in crops of the same family of beans by other authors (Hoffmann-Campo, 1995; Salunke et al., 2005; HoffmannCampo et al., 2006; Souza, 2014; Lima et al., 2014). Analyses were performed using the method proposed by Perlatti et al. (2015), therefore, the equipment set Agilent 1200 series (Agilent Technologies, Santa Clara, USA) coupled to a mass spectrometer API 2000TM Triple Quadrupole Mass Spectrometer (AB/MDS Sciex, CA USA).

An Alltech Prevail ${ }^{\circledR}$ C18 column (particle size $3 \mu \mathrm{m}$; $2.1 \times 100 \mathrm{~mm}$ ) was used and column oven kept at $35^{\circ} \mathrm{C}$. As mobile phase, an acetic acid solution in deionized water $(0.5 \%: \mathrm{v} / \mathrm{v})(\mathrm{A}$ solvent) and acetic acid solution in acetonitrile $(0.5 \%: \mathrm{v} / \mathrm{v})$ (B solvent). The method was developed in the gradient mode, with the first six minutes at 75:25 A: B ration; then, progressing to 10:90 in half a minute, which was maintained for thirteen and a half minutes, with a total run time of twenty minutes. The flow rate was kept at $250 \mu \mathrm{L} \mathrm{min}{ }^{-1}$, and for each sample, it was injected $5 \mu \mathrm{L}$. The chromatograph output was coupled to a flow divider where $20 \mu \mathrm{L} \mathrm{min}{ }^{-1}$ was targeted to a triple quadrupole API ${ }^{\circledR} 2000$ mass spectrometer (AB/MDS Sciex, Framingham, MA, USA) operated with a source of electrospray ionization (ESI) in negative mode.

Quantitation was performed using a selected reaction monitoring (SRM) mode, where reactions between characteristic ions are used to specify each analyte within the matrix. Quantitative evaluation was carried individually based on calibration curve for external standardization and regression analysis. The software used to operate the equipment and perform data treatments was Analyst 1.5.1 version.

\subsection{Statistical analyses}

Within univariate data analysis, the grain average was calculated for each parameter, and subsequently averaged 8 grains, so the 40 grains were grouped into 5 groups (replications), for which a completely randomized design was adopted with 43 genotypes (treatments) and 5 replicates.

Data underwent homoscedasticity test Levene $(\alpha=0.05)$ and normality test Cramer Von Misses $(\alpha=0.05)$, and submitted to ANOVA test $(\alpha=0.05)$ by SAS 9.3 software (Sas Institute, 2011); when significant, averages were compared by the Scott-Knott test $(\alpha=0.05)$ using SISVAR 5.3 (Ferreira, 2011). Data that showed no variance homogeneity and normal distribution underwent the Kruskal-Wallis test $(\alpha=0.05)$ by SAS 9.3 software (Sas Institute, 2011); aversely when significant, the Dunn's test was performed $(\alpha=0.05)$ through Prism 4 (Graphpad, 2003). Values of the correlation coefficient were calculated from departure zero using a 2tailed t-test with n-2 degrees of freedom, with the aid of the software Statistica 7 (Statsoft, 2004).

In the multivariate analysis, for each variable was calculated the treatment average and subjected to the hierarchical cluster analysis (HCA) by Ward's method, using the Euclidean distance as the dissimilarity measure. In addition, we performed the principal component analysis (PCA) to identify the parameters that most influenced the separation of groups. The multivariate analyses were performed in the Statistica 7 software (Statsoft, 2004). With the results from the HCA e PCA analyses, it was possible to determine which group separation better represented the resistance levels of the genotypes, being the "cut off" in the Euclidean distance of the linkage between 8.81 and 11.01 .

\section{Results}

For bean resistance identification, several biological parameters of $Z$. subfasciatus were assessed. Therefore, we observed a significant difference between the genotypes within larva to adult periods, whereas genotype 173 was significantly different from 280 , the latter with shorter duration $\left(H_{34,118}=63.26, P=<0.01\right)$ (Fig. 1$)$. In the other development stages egg to larvae hatching (egg to larvae) $\left(F_{42,172}=0.71, P=0.91\right)$, longevity $\left(F_{34,118}=1.51, P=0.05\right)$ and egg to adult death (life cycle) $\left(F_{34}, 118=1.06, P=0.39\right.$ ), no differences were observed among genotypes. It was not possible to analyze statistically the weevils development in 177, 283, Raz 59, $364,179,282$ and 361 genotypes, due to the low adult emergence in these genotypes (Fig. 1).

Egg viability were high for all genotypes, over $75 \%$ and there was 


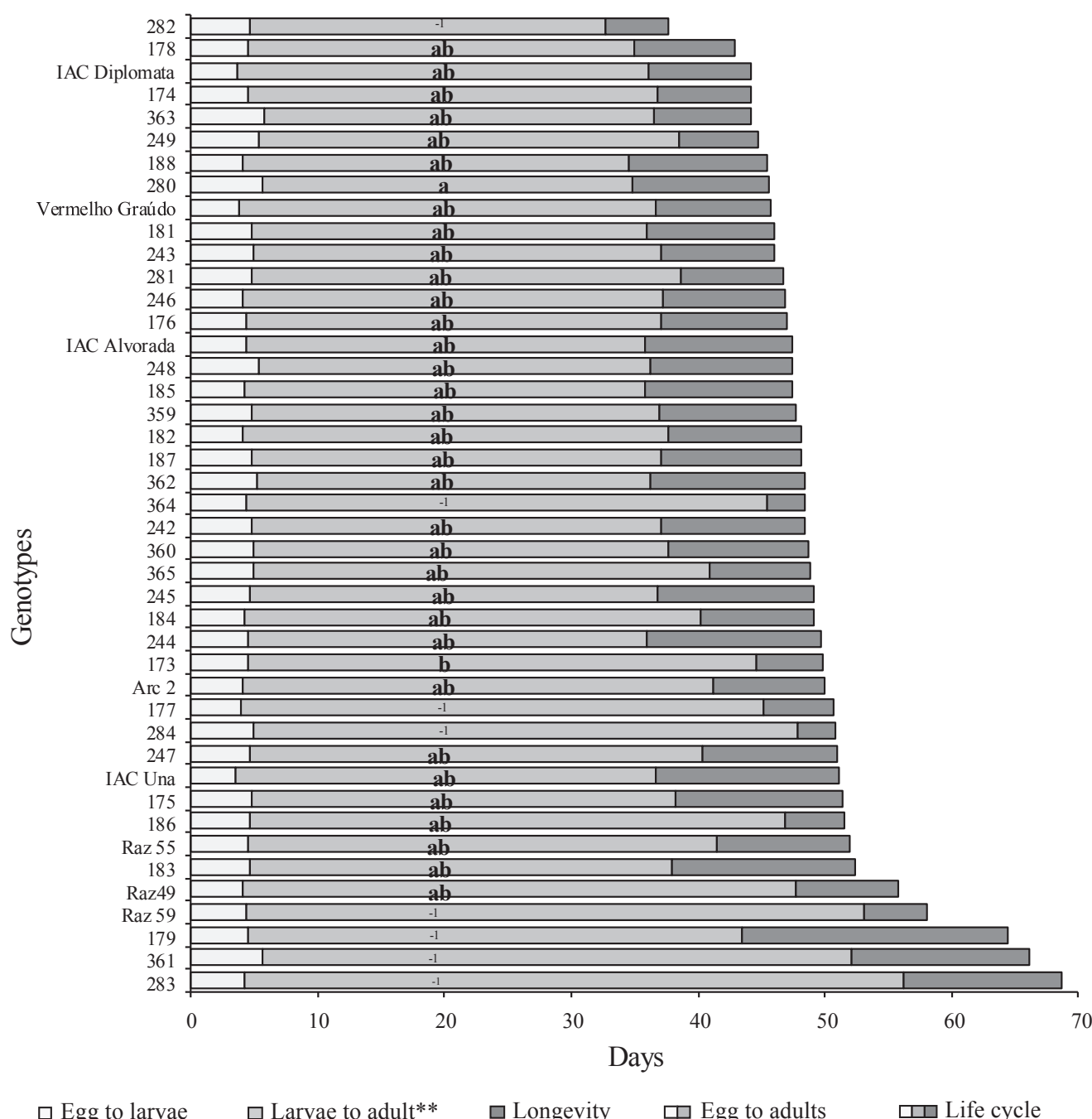

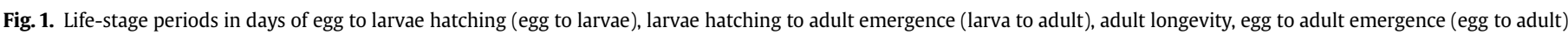

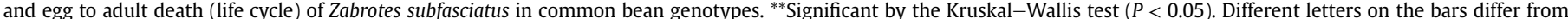
each other by the Dunn's test $(P<0.05){ }^{-1}$ Insufficient data for statistics.

no significant difference between them $\left(H_{42,172}=49.71, P=0.19\right)$. Regarding emerged adults, it is noteworthy to mention that the majority of larvae were disfavored when fed in Arc 2, Raz 49, Raz 55, Raz 59, 173, 174, 175, 177, 179, 186, 242, 245, 247, 249, 281, 282, $283,284,361,362,363,364$ and 365 genotypes. Since only $16 \%$ of the hatched larvae were able to reach adulthood, differentiating significantly of the adults emerged in the other genotypes $\left(F_{42}\right.$, $172=4.77, P=<0.01$ ). It stands out even in genotypes $179,364,282$ and 284 less than $1.4 \%$ of larvae were able to complete their life cycle (Table 2).

We observed with the susceptibility relative index (SRI) that the genotypes Vermelho Graúdo, IAC Alvorada, IAC Diplomata, 178, 181, $185,188,248,280,359$, and 360 did not differ from IAC Una (susceptible genotype standard), but differed from other genotypes with lower SRI $\left(F_{33,113}=1.74, P=0.03\right)$, including the genotype Raz 49 , used as the resistance standard (Table 2). It was not possible to analyze statistically the SRI of some genotypes due to the low number of replicates and/or the variances were null, being the low number of emerged adults responsible for both cases.

Because of high mortality in immature phases, it was not possible to analyze statistically weevils weight and sex ratio for some genotypes. Beetle weight and sex ratio had no significant differences $\left(F_{34,118}=1.15, P=0.30\right)$; $\left(H_{34,118}=25.78, P=0.84\right)$ for all genotypes. Grain dry mass consumed by bruchid larvae was significantly lower for Arc 2, Raz 49, 173, 177, 179, 182, 186, 187, 247, $249,362,363,364,365,282,283$ and $284\left(F_{42,172}=4.10, P=<0.01\right)$ (Table 2), being highlighted as it was $92.4 \%$ less consumed than Vermelho Graúdo.

We established the "cut off" between the Euclidean distances from 8.81 to 11.01 (dotted lines) based on both results of the HCA and PCA analyses, being possible to observe that group separation in this "cut off" line better represented the obtained results. Thus, genotypes were distinct among each other, and were separated into four groups according to their similarity degree (Fig. 2).

The first group (G1) was formed by the genotypes 283, 361 and 179 , classified as highly resistant. The second group (G2) was composed of 284, 186, 173, 364, Raz 59, 177 and Raz 49, classified as moderately resistant. Moreover, the third group (G3) integrated the largest amount of the genotypes 184, 181, 178, 185, 176, 174, 188, 246, IAC Diplomata, 822, 363, 249, 360, 359, 280, 248, 281, 243, 245 244, 242, 362, 365, 287, 247, Raz 55, 182 and Arc 2, which was classified as susceptible. Finally, the fourth and last group (G4) included 175, 183, IAC Una, IAC Alvorada and Vermelho Graúdo, being classified as highly susceptible (Fig. 2). 
Table 2

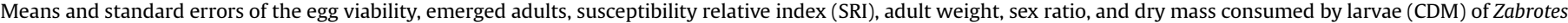
subfasciatus in common bean genotypes.

\begin{tabular}{|c|c|c|c|c|c|c|}
\hline Genotypes & Egg viability (\%) & Emerged adults (\%) & SRI & Adult weight (mg) & Sex ratio & $\mathrm{CDM}$ (mg) \\
\hline Vermelho Graúdo & $82.5 \pm 2.34$ & $34.3 \pm 5.01 \mathrm{~b}$ & $107.0 \pm 13.25 b$ & $2.4 \pm 0.22$ & $0.4 \pm 0.10$ & $10.6 \pm 2.44 b$ \\
\hline Arc 2 & $95.0 \pm 1.24$ & $10.0 \pm 0.52 \mathrm{a}$ & $27.2 \pm 11.14 \mathrm{a}$ & $2.3 \pm 0.31$ & $0.4 \pm 0.19$ & $2.1 \pm 0.32 \mathrm{a}$ \\
\hline IAC Alvorada & $90.0 \pm 4.68$ & $37.9 \pm 9.99 b$ & $112.7 \pm 21.73 b$ & $2.7 \pm 0.21$ & $0.5 \pm 0.16$ & $8.5 \pm 1.69 b$ \\
\hline IAC Diplomata & $91.3 \pm 3.74$ & $29.3 \pm 8.02 b$ & $95.2 \pm 19.08 b$ & $2.5 \pm 0.20$ & $0.4 \pm 0.12$ & $3.9 \pm 1.16 b$ \\
\hline IAC Una & $91.3 \pm 5.44$ & $30.9 \pm 6.76 b$ & $100.0 \pm 19.47 b$ & $2.6 \pm 0.15$ & $0.7 \pm 0.11$ & $7.7 \pm 1.87 \mathrm{~b}$ \\
\hline Raz 49 & $97.5 \pm 1.52$ & $8.8 \pm 4.68 \mathrm{a}$ & $40.2 \pm 25.93 \mathrm{a}$ & $2.3 \pm 0.21$ & $0.6 \pm 0.31$ & $2.6 \pm 0.66 a$ \\
\hline Raz 55 & $93.8 \pm 4.84$ & $7.5 \pm 2.34 \mathrm{a}$ & $20.9 \pm 12.23 \mathrm{a}$ & $2.8 \pm 0.31$ & $0.5 \pm 0.29$ & $4.4 \pm 0.59 b$ \\
\hline Raz 59 & $95.0 \pm 5.00$ & $8.8 \pm 7.29 a$ & -1 & -1 & -1 & $3.6 \pm 0.65 b$ \\
\hline 173 & $95.0 \pm 3.63$ & $5.2 \pm 1.31 \mathrm{a}$ & -2 & $1.9 \pm 0.33$ & $0.3 \pm 0.25$ & $1.8 \pm 0.33 a$ \\
\hline 174 & $97.5 \pm 1.52$ & $11.3 \pm 3.65 a$ & $50.6 \pm 18.23 \mathrm{a}$ & $2.4 \pm 0.31$ & $0.5 \pm 0.21$ & $4.0 \pm 1.41 \mathrm{~b}$ \\
\hline 175 & $77.5 \pm 5.08$ & $15.5 \pm 5.71 \mathrm{a}$ & $61.9 \pm 24.21 \mathrm{a}$ & $2.6 \pm 0.27$ & $0.4 \pm 0.13$ & $4.4 \pm 1.21 \mathrm{~b}$ \\
\hline 176 & $96.3 \pm 2.50$ & $23.8 \pm 7.23 b$ & $74.5 \pm 24.21 \mathrm{a}$ & $2.7 \pm 0.31$ & $0.6 \pm 0.17$ & $4.1 \pm 0.70 b$ \\
\hline 177 & $96.3 \pm 1.52$ & $8.8 \pm 6.13 a$ & -1 & -1 & -1 & $1.8 \pm 0.47 a$ \\
\hline 178 & $96.3 \pm 1.52$ & $26.3 \pm 5.73 b$ & $95.0 \pm 17.90 \mathrm{~b}$ & $3.0 \pm 0.41$ & $0.5 \pm 0.17$ & $4.5 \pm 1.37 b$ \\
\hline 179 & $95.0 \pm 3.63$ & $1.3 \pm 1.26 \mathrm{a}$ & -1 & -1 & -1 & $2.3 \pm 1.07 \mathrm{a}$ \\
\hline 181 & $97.5 \pm 2.50$ & $27.5 \pm 4.24 b$ & $100.9 \pm 12.92 b$ & $2.7 \pm 0.22$ & $0.4 \pm 0.04$ & $4.2 \pm 0.33 b$ \\
\hline 182 & $97.5 \pm 1.52$ & $20.0 \pm 4.14 b$ & $70.0 \pm 18.30 \mathrm{a}$ & $2.4 \pm 0.17$ & $0.5 \pm 0.17$ & $2.3 \pm 0.36 a$ \\
\hline 183 & $88.8 \pm 5.37$ & $26.4 \pm 6.93 \mathrm{~b}$ & $78.1 \pm 21.66 \mathrm{a}$ & $2.9 \pm 0.30$ & $0.7 \pm 0.17$ & $5.1 \pm 1.01 b$ \\
\hline 184 & $96.3 \pm 3.75$ & $21.3 \pm 3.19 b$ & $75.9 \pm 9.98 a$ & $2.7 \pm 0.16$ & $0.7 \pm 0.12$ & $5.1 \pm 1.61 b$ \\
\hline 185 & $98.8 \pm 1.24$ & $26.3 \pm 7.77 b$ & $117.4 \pm 13.18 b$ & $2.5 \pm 0.19$ & $0.6 \pm 0.13$ & $3.9 \pm 0.67 b$ \\
\hline 186 & $97.5 \pm 1.52$ & $3.8 \pm 1.54 \mathrm{a}$ & & $1.2 \pm 0.08$ & $0.0 \pm 0.00$ & $1.1 \pm 0.36 a$ \\
\hline 187 & $91.3 \pm 3.74$ & $18.2 \pm 2.79 b$ & $67.5 \pm 10.53 a$ & $2.4 \pm 0.35$ & $0.5 \pm 0.16$ & $2.4 \pm 0.73 a$ \\
\hline 188 & $93.8 \pm 2.80$ & $24.7 \pm 8.94 b$ & $103.0 \pm 34.57 b$ & $2.5 \pm 0.13$ & $0.5 \pm 0.18$ & $4.6 \pm 0.92 b$ \\
\hline 242 & $91.3 \pm 3.75$ & $13.9 \pm 6.63 a$ & $54.1 \pm 33.03 \mathrm{a}$ & $2.4 \pm 0.35$ & $0.4 \pm 0.24$ & $5.0 \pm 0.94 b$ \\
\hline 243 & $91.3 \pm 3.75$ & $18.6 \pm 4.81 b$ & $62.1 \pm 19.89 a$ & $3.0 \pm 0.51$ & $0.7 \pm 0.13$ & $3.9 \pm 0.86 b$ \\
\hline 244 & $91.3 \pm 4.68$ & $17.7 \pm 4.91 b$ & $58.9 \pm 25.32 \mathrm{a}$ & $2.7 \pm 0.43$ & $0.6 \pm 0.23$ & $4.5 \pm 0.47 b$ \\
\hline 245 & $96.3 \pm 2.50$ & $11.4 \pm 5.70 \mathrm{a}$ & $65.7 \pm 32.94 \mathrm{a}$ & $2.5 \pm 0.15$ & $0.6 \pm 0.21$ & $3.4 \pm 0.16 b$ \\
\hline 246 & $91.3 \pm 4.68$ & $21.8 \pm 5.03 b$ & $75.0 \pm 21.45 \mathrm{a}$ & $2.3 \pm 0.19$ & $0.3 \pm 0.16$ & $4.4 \pm 0.63 b$ \\
\hline 247 & $93.8 \pm 1.98$ & $7.5 \pm 3.65 a$ & $39.5 \pm 20.10 a$ & $2.7 \pm 0.37$ & $0.6 \pm 0.33$ & $2.9 \pm 0.62 a$ \\
\hline 248 & $97.5 \pm 1.52$ & $33.8 \pm 5.80 \mathrm{~b}$ & $112.7 \pm 16.74 b$ & $2.5 \pm 0.07$ & $0.4 \pm 0.06$ & $4.4 \pm 0.62 b$ \\
\hline 249 & $97.5 \pm 1.52$ & $11.3 \pm 6.67 \mathrm{a}$ & $33.4 \pm 33.41 \mathrm{a}$ & $2.2 \pm 0.22$ & $0.4 \pm 0.24$ & $2.0 \pm 0.53 a$ \\
\hline 280 & $96.3 \pm 1.52$ & $25.0 \pm 7.91 b$ & $85.1 \pm 28.04 b$ & $2.7 \pm 0.22$ & $0.5 \pm 0.16$ & $4.4 \pm 0.49 b$ \\
\hline 281 & $88.8 \pm 4.59$ & $7.5 \pm 3.06 a$ & $47.3 \pm 3.80 \mathrm{a}$ & $2.7 \pm 0.40$ & $0.8 \pm 0.16$ & $4.5 \pm 1.60 b$ \\
\hline 282 & $92.5 \pm 6.05$ & $1.3 \pm 1.26 \mathrm{a}$ & -1 & -1 & -1 & $1.0 \pm 0.57 a$ \\
\hline 283 & $88.7 \pm 5.37$ & $3.8 \pm 2.50 a$ & -1 & -1 & -1 & $1.6 \pm 0.65 \mathrm{a}$ \\
\hline 284 & $96.3 \pm 2.50$ & $1.3 \pm 1.26 \mathrm{a}$ & -1 & -1 & -1 & $0.8 \pm 0.27 a$ \\
\hline 359 & $88.8 \pm 4.15$ & $34.5 \pm 3.39 b$ & $116.0 \pm 7.98 \mathrm{~b}$ & $2.6 \pm 0.31$ & $0.4 \pm 0.05$ & $4.9 \pm 0.74 b$ \\
\hline 360 & $91.3 \pm 3.18$ & $28.8 \pm 8.05 b$ & $95.6 \pm 26.46 b$ & $2.2 \pm 0.72$ & $0.3 \pm 0.13$ & $3.7 \pm 0.26 b$ \\
\hline 361 & $87.5 \pm 6.56$ & $2.5 \pm 1.54 \mathrm{a}$ & -1 & -1 & -1 & $4.5 \pm 1.92 b$ \\
\hline 362 & $96.3 \pm 2.50$ & $14.3 \pm 4.34 \mathrm{a}$ & $67.7 \pm 10.20 \mathrm{a}$ & $2.3 \pm 0.35$ & $0.4 \pm 0.24$ & $2.3 \pm 0.75 a$ \\
\hline 363 & $96.3 \pm 1.52$ & $6.3 \pm 2.80 \mathrm{a}$ & $33.9 \pm 16.95 a$ & $2.5 \pm 0.53$ & $0.5 \pm 0.29$ & $2.3 \pm 0.37 a$ \\
\hline 364 & $93.8 \pm 2.80$ & $1.3 \pm 1.30 \mathrm{a}$ & -1 & -1 & -1 & $2.1 \pm 0.25 a$ \\
\hline 365 & $91.3 \pm 3.19$ & $12.5 \pm 3.44 \mathrm{a}$ & $66.3 \pm 10.38 a$ & $2.5 \pm 0.36$ & $0.4 \pm 0.25$ & $2.6 \pm 0.67 a$ \\
\hline
\end{tabular}

Means with different letters in the column differ from each other by the Scott-Knott test $(P<0.05) .{ }^{-1}$ Insufficient data for statistics analysis, ${ }^{-2}$ Data with null variances.

In principal component analysis-PCA (Fig. 3), highly resistant genotypes 283, 361 and 179 were located to the left of the third quadrant, and were mainly influenced by higher life cycles. The genotype 282, isolated at the top of the first quadrant, was also considered highly resistant, since beetles found in this genotype had low rates of consumption and emerged adults, which denotes resistance characteristic, despite the short life cycle that is a characteristic of susceptibility, which explains its position within the upper part of the first quadrant.

In the second quadrant are found the moderately resistant genotypes on the left, which are mostly influenced by low rates of emerged adults and dry matter consumption, standing out 284, $186,173,177$ and 364; and for longer periods of egg to adult and larva to adult, highlighting Raz 49 and Raz 59, respectively (Fig. 3).

When considered singly, parameters had little influence on susceptible genotypes, remaining within the center of the PCA. Weevil larvae from IAC Una, IAC Alvorada, Vermelho Graúdo, located within the lower right of fourth quadrant were mostly affected by the greater amount of consumed dry mass and higher percentage of adults emerged. Yet the genotypes 175 and 183 were biased by insect longevity, being part of the highly susceptible group (Fig. 3).
LC-MS/MS showed detection limits within the range of $1 \mu \mathrm{g} / \mathrm{g}$; nevertheless, among the nine analyzed compounds, only isoquercitrin was above quantification limit in bean genotypes, in amounts ranging from 1.90 to $84.70 \mu \mathrm{g} / \mathrm{g}$ for IAC Alvorada and 178 , respectively. Nonetheless, there was no significant correlation between isoquercetrin and any of the biological parameters tested ( $\mathrm{r}$ values ranged between -0.26 and 0.14 ).

\section{Discussion}

Based on results of univariate and multivariate analyses, the genotypes could be identified and classified into resistance level groups on antibiosis, showing which parameters have most influenced clustering. The results were only possible because of the use of both analysis, being the univariate critical to understanding the multivariate, which, in turn, was able to group the genotypes considering all assessed parameters at the same time. Costa et al. (2013) pointed out the importance of multivariate analysis to discriminate genotypes with similar characteristics to each other, and then gathering them according to these features.

Genotypes were classified into four resistance levels highly resistant, moderately resistant, susceptible and highly susceptible. 


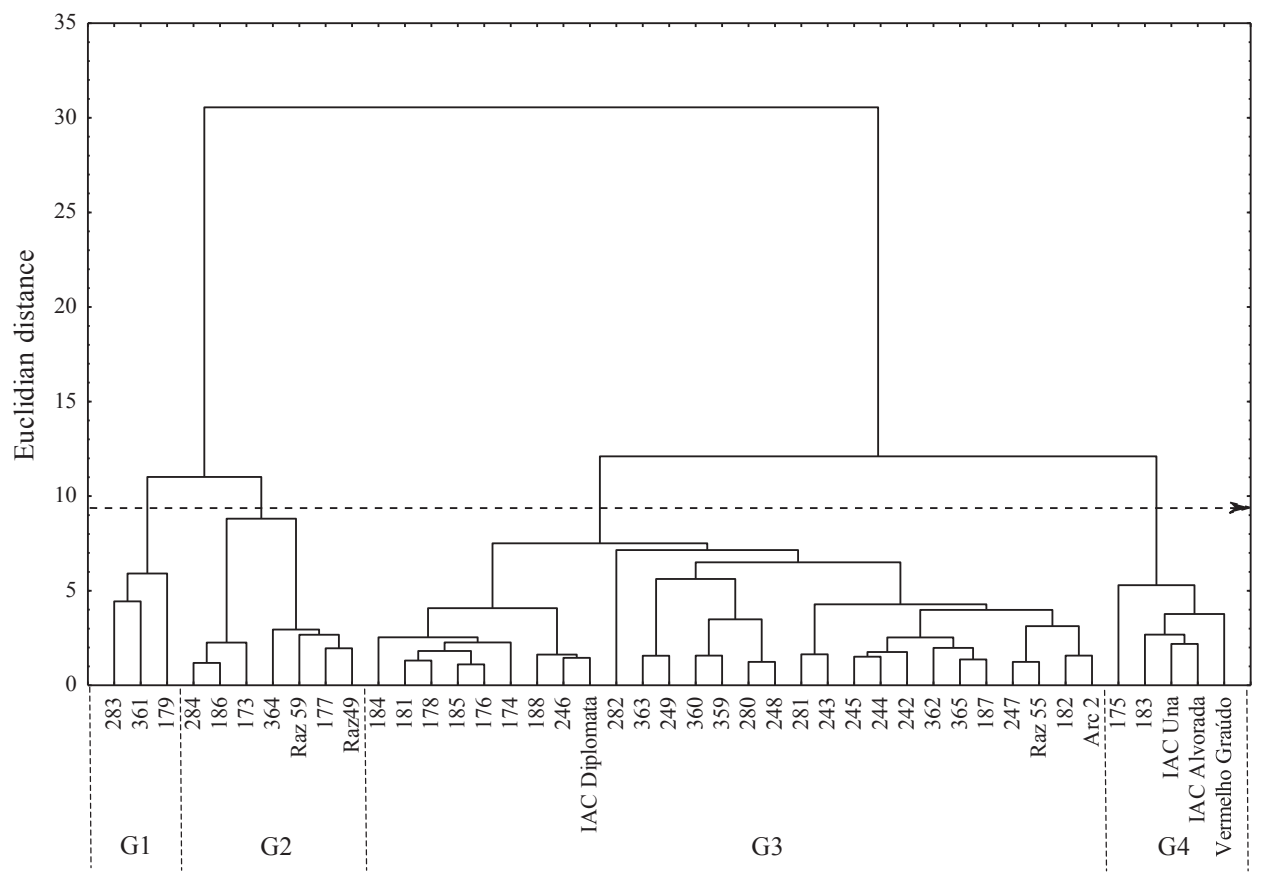

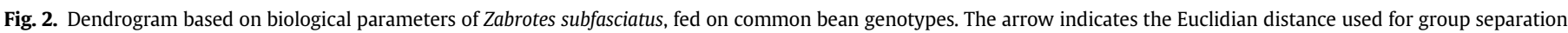
First group (G1), second group (G2), third group (G3), and fourth group (G4).

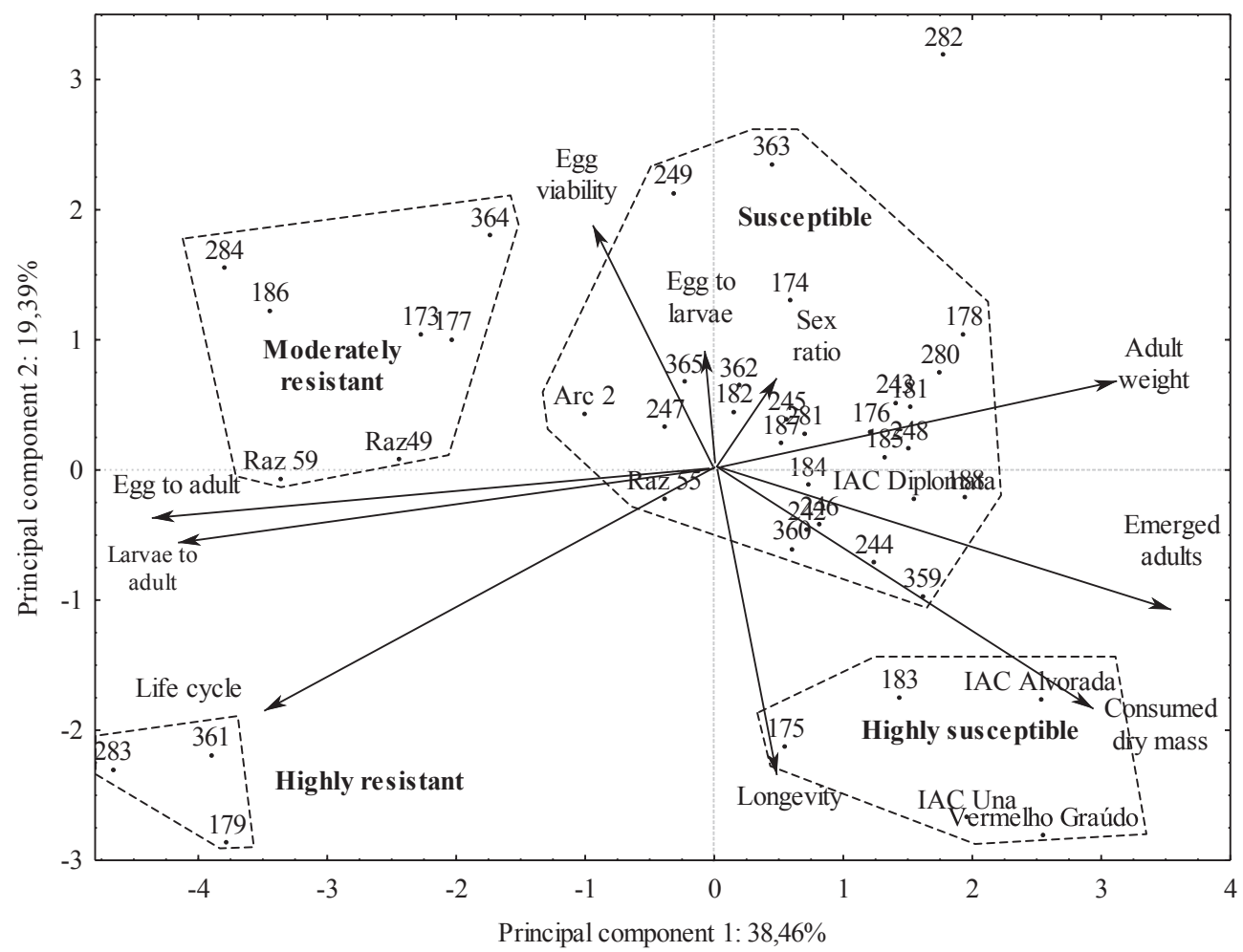

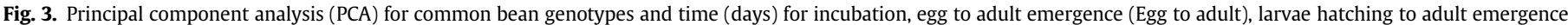

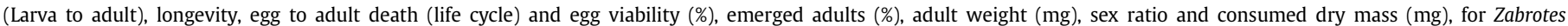
subfasciatus.

The genotypes considered highly resistant (361, 283, 179 and 282) were mainly affected by longer pest life cycles, except for 282 , which had shown low consumption and percentage of emerging adults.
Longer development periods of this pest were also observed in arcelin-bearing genotypes by Wanderley et al. (1997) using Arc 1, Miranda et al. (2002) evaluating Arc 1 and Arc 4; and studies by Mazzonetto and Vendramim (2002) with Arc 1, Arc 2, 3 and Arc 4. 
Although the amount of arcelin has not been analyzed, the genotypes 361, 283 and 179 may possess arcelin concentrations, derived from their parental, which could increase the life cycle of the weevils.

Genotypes categorized as moderately resistant were primarily affected by lower rates of adult emergence, lower dry mass consumption and long periods from egg to adult and larva to adult. High mortality of immature stages characterizes resistant genotypes regarding antibiosis category (Boiça Júnior et al., 2015). Schoonhoven and Cardona (1982) also reported that low adult emergence and long egg-to-adult period are parameters indicating bean resistance to weevils, which could be observed in moderately and highly resistant materials. These genotypes showed a lower consumption of dry mass, suggesting that food had some antibiotic compound that harm the development of the larvae, occasioning death, thereby decreasing their feeding. Moraes et al. (2011) observed that bean genotypes with arcelin protein possibly interfered with $Z$. subfasciatus feeding, considering such protein as responsible for antibiotic resistance of wild beans against bruchid beetles (Osborn et al., 1986).

Besides chemical reasons or nutritional inadequacy, there might be other causes of poor larvae feeding such as morphological ones. Vieira et al. (2005) cited seed coat hardness as one morphological aspects of weevil resistance of bean cultivars. However, it was apparent through our study that some compound plays an antibiotic role because there was a high viability of eggs in all genotypes, indicating that the majority of the larvae fed and penetrated into the grain, discarding the effect of hard seed coats as the resistance mechanism. There was significant difference in the evaluation of larvae that did not reach adulthood (percentage of emerged adults), being very low in some genotypes, proving that the larvae did not develop due to some compound ingested during their feeding.

The susceptibility relative index (SRI), calculated based on the standard susceptible genotype IAC Una, was greater for genotypes IAC Alvorada, Vermelho graúdo, IAC Diplomata, 178, 181, 185, 188, $248,280,359,360$, including IAC Una, characterizing them as susceptible. All these genotypes are classified into groups of susceptible or highly susceptible genotypes by multivariate analysis, demonstrating the robustness of the group separation through multivariate results. However, some genotypes with low SRI were classified based on the multivariate analysis in the group of the susceptible genotypes; this occurred because the multivariate analysis takes in consideration all parameters together, while the SRI bases on the number of emerged weevils and the average time spent for their development (Dobie, 1977). What may have occurred was that these genotypes had closer results to the susceptible genotypes for other parameters evaluated, thus characterizing their classification into this group through the multivariate analyses.

Susceptible genotypes had no influence by a single parameter, remaining close to the average compared to all parameters, being situated in the middle of principal components. The highest rates of emerged adults, greater dry mass consumption and longer-lived adults mostly biased highly susceptible genotypes. Although all crosses contain a parent with resistance characteristics, various genotypes failed to express it and/or inherited more characteristics of susceptibility belonging to the more productive parents.

Overall, the parameters that most influenced the classification of the genotypes into four levels of resistance to $Z$. subfasciatus, according to the principal component analysis, were the periods from egg to adult emergence, period from larvae hatching to adult emergence, period from egg to adults death (cycle life), percentages of emerged adults, and dry mass consumed. Based on this, longer periods of development may be related to reductions in feeding habit, which negatively affects the rates of adult emergence.
Regarding qualitative analysis, isoquercitrin was the only flavonoid found; however, no significant correlation with the biological parameters of $Z$. subfasciatus was observed; thus, we can assume that such flavonoid has no influence on resistance expression. Furthermore, it could not be discarded the hypothesis of other flavonoids, non-evaluated, would be forerunners of the resistance; since several other authors had observed singly the effect of certain flavonoids affecting adversely insect pests (Isman and Duffey, 1983; Gazzoni et al. (1997), Hoffmann-Campo et al., 2006, Piubelli et al., 2006).

The methodology evaluated the period from egg to larvae, which is usually non-input in similar studies (Ribeiro-Costa et al., 2007; Baldin and Pereira, 2010; Moraes et al., 2011; Costa et al., 2013). This parameter can show if larvae had problems to penetrate grains, and then pointing morphological factors as a cause of resistance. Additionally, this methodology has facilitated evaluating a large number of genotypes at the same time, what could be quite useful in breeding programs.

Our results are promising since some bean genotypes stood out as resistant, being classified into four antibiosis-resistance levels against $Z$. subfasciatus, which were highly resistant, moderately resistant, susceptible, and highly susceptible. The following parameters most influenced this classification: egg to adult and larva to adult periods, life cycle, rate of emerged adults, and consumed dry mass. Only isoquercitrin out of the eight flavonoids evaluated was quantified in the common bean genotypes, and there is no statistical correlation between this flavonoid and weevil resistance. Further studies are still needed aiming at better discriminating the main mechanisms responsible for the expression of resistance against the bean weevil, as well as knowing their agronomic importance, besides discovering other possible sources of resistance associated with other insect pests and diseases for later marketing of the bean genotypes.

\section{Acknowledgments}

The authors want to thank the Brazilian Council for Scientific and Technological Development - CNPq (Conselho Nacional de Desenvolvimento Científico e Tecnológico - CNPq) for granted Master's degree scholarship to the first author (131324/2012-8) and second author's productivity in research grant.

\section{References}

Baldin, E.L.L., Pereira, J.M., 2010. Resistência de genótipos de feijoeiro a Zabrotes subfasciatus (Boheman, 1833) (Coleoptera: Bruchidae). Ciência Agrotecnol. 34, 1507-1513.

Boiça Júnior, A.L., Souza, B.H.S., Ribeiro, Z.A., Moraes, R.F.O., Eduardo, W.I., Nogueira, L., 2015. A defesa das plantas ao ataque dos insetos. In: Busoli, A.C., Castilho, R.C., Andrade, D.J., Rossi, G.D., Viana, D.L., Fraga, D.F., Souza, L.A. (Eds.), Tópicos em Entomologia Agrícola - VIII. Gráfica e editora Multipress, Jaboticabal, pp. 207-224.

Barbosa, F.R., Yokoyama, M., Pereira, P.A.A., Zimmermann, F.J.P., 1999. Effect of arcelin protein on the biology of Zabrotes subfasciatus (Boheman 1833), in dry beans. Pesqui. Agropecuária Bras. 34, 1805-1810.

Cardona, C., Kornegay, J., Posso, C.E., Morales, F., Ramirez, H., 1990. Comparative value of four arcelin variants in the development of dry bean lines resistant to the Mexican bean weevil. Entomol. Exp. Appl. 56, 197-206.

Costa, E.N., Souza, B.H.S., Bottega, D.B., Oliveira, F.Q.O., Ribeiro, Z.A., Boiça Júnior, A.L., 2013. Divergência genética de genótipos de feijoeiro a infestação de Zabrotes subfasciatus (Bohemann) (Coleoptera: Bruchidae). Semina 34, 2737-2752.

Dobie, P., 1977. The contribution of the tropical stored products centre to the study of insect resistance in stored maize. Trop. Stored Prod. Inf. 34, 7-22.

Ferreira, D.F., 2011. Sisvar: a computer statistical analysis system. Ciência Agrotecnol. 35, 1039-1042.

Gazzoni, D.L., Hulsmeyer, A., Hoffmann-Campo, C.B., 1997. Efeito de diferentes doses de rutina e quercetina na biologia de Anticarsia gemmatalis. Pesqui. Agropecuária Bras. 32, 673-681.

Gatehouse, A.M.R., Gatehouse, J.A., Dobie, P., Kliminster, A.M., Boulter, D. Biochemical basis of insect resistance in Vigna unguiculata. J. Sci. Food Agric., 30, 
948-958.

Graphpad, 2003. GraphPad Prism Version 4.00. EUA, San Diego.

Harborne, J.B., Williams, C.A., 2000. Advances in flavonoid research since 1992. Phytochemistry 55, 481-504.

Hoffmann-Campo, C.B., 1995. Role of the Flavonoids in the Natural Resistance of Soybean to Heliothis virescens (F.) and Trichoplusi ni (Hübner). 165 f. Tese (Doutorado em Botânica). The University of Reading, Reading.

Hoffmann-Campo, C.B., Ramos Neto, J.A., Oliveira, M.C., Oliveira, L.J., 2006. Detrimental effect of rutin on Anticarsia gemmatalis. Pesqui. Agropecuária Bras. 41, 1453-1459.

Iac - Agronomic Institute of Campinas, 2013. Centro de Grãos e Fibras - Cultivares de Feijão. Available in. http://www.iac.sp.gov.br/areasdepesquisa/graos/feijao. php (accessed 09.12.13.)

Isman, M.B., Duffey, S.S., 1983. Pharmacokinetics of chlorogenic acid and rutin in larvae of Heliothis zea. J. Insect Physiol. 29, 295-300.

Janarthanan, S., Suresh, P., 2003. Insecticidal potential of wild bean seed protein, arcelin. Nat. Product. Radiance 2, 243-245.

Janarthanan, S., Suresh, P., Radke, G., Morgan, D., Oppert, B., 2008. Arcelin from Indian wild pulse, L. purpureus and insecticidal activity in storage pests. J. Agric. Food Chem. 56, 1676-1682.

Lima, P.F., Colombo, C.A., Chiorato, A.F., Yamaguchi, L.F., Kato, M.J., Carbonell, S.A., 2014. Occurrence of isoflavonoids in Brazilian common bean germplasm (Phaseolus vulgaris L.). J. Agric. Food Chem. 62, 9699-9704.

Macedo, M.L.R., Andrade, L.B.S., Moraes, R.A., Xavier-Filho, J., 1993. Vicilin variants and the resistance of cowpea (Vigna unguiculata) seeds to the cowpea weevil (Callosobruchus maculatus). Comp. Biochem. Physiol. 105, 89-94.

Mazzonetto, F., Vendramim, J.D., 2002. Aspectos biológicos de Zabrotes subfasciatus (Boh.) (Coleoptera: Bruchidae) em genótipos de feijoeiro com e sem arcelina. Neotropical Entomol. 31, 435-439.

Miranda, J.E., Toscano, L.C., Fernandes, M.G., 2002. Avaliação da resistência de diferentes genótipos de Phaseolus vulgaris a Zabrotes subfasciatus (Boh.) Coleoptera: Bruchidae). Bol. Sanid. Vegetal Plagas 28, 571-576.

Moraes, C.P.B., Boiça Júnior, A.L., Souza, J.R., Costa, J.T., 2011. Determinação dos tipos de resistência em genótipos de feijoeiro ao ataque de Zabrotes subfasciatus (Coleoptera: Bruchidae). Ceres 58, 419-424.

Osborn, T.C., Alexander, D.C., Sun, S.S.M., Cardona, C., Bliss, F.A., 1988. Atividade inseticida e lectina de homologia da proteína arcelina semente. Science 240, 207-210.

Osborn, T.C., Blake, T., Gepts, P., Bliss, F.A., 1986. Bean arcelin, 2: genetic variation, inheritance and linkage relationships of a novel seed protein of Phaseolus vulgaris L. Theor. Appl. Genet. 71, 847-855.

Perlatti, B., Fernandes, J.B., Silva, M.F.G.F., Ardila, J.A., Carneiro, R.L., Souza, B.H.S., Costa, E.N., Eduardo, W.I., Boiça Junior, A.L., Forim, M.R., 2015. Application of a quantitative HPLC-ESI-MS/MS method for flavonoids in different vegetables matrices. J. Braz. Chem. Soc. http://dx.doi.org/10.5935/0103-5053.20150273.
Piubelli, G.C., Hoffmann-Campo, C.B., Moscardi, F., Miyakubo, S.H., Oliveira, M.C.N. 2006. Baculovirus-resistant Anticarsia gemmatalis responds differently to dietary rutin. Entomol. Exp. Appl. 119, 53-60.

Ribeiro-Costa, C.S., Pereira, P.R.V.S., Zukovski, L., 2007. Desenvolvimento de Zabrotes subfasciatus (Boh.) (Coleoptera: Chrysomelidae, Bruchinae) em genótipos de Phaseolus vulgaris L. (Fabaceae) cultivados no estado do Paraná e contendo arcelina. Neotropical Entomol. 36, 560-564.

Sales, M.P., Andrade, L.B.S., Miranda, M.R.A., Teixeira, F.M., Oliveira, A.S. Fernandes, K.V.S., Xavier-Filho, J., 2005. Performance of bean bruchids Callosobruchus maculatus and Zabrotes subfasciatus (Coleoptera: Bruchidae) reared on resistant (IT81D-1045) and susceptible (Epace 10) Vigna unguiculata seeds: relationship with trypsin inhibitor and vicilin excretion. Comp. Biochem. Physiol. Part A Mol. Integr. Physiol. 142, 422-426.

Salunke, B.K., Kotkar, H.M., Mendki, P.S., Upasani, S.M., Maheshwari, V.L., 2005. Efficacy of flavonoids in controlling Callosobruchus chinensis (L.) (Coleoptera: Bruchidae), a post-harvest pest of grain legumes. Crop Prot. 24, 888-893.

Sas Institute, 2011. Sas/Stat User Software: Changes and 14 Enhancements through Release. Estados Unidos, Cary. Version 9.3.

Schoonhoven, A., Cardona, C. van, 1982. Low levels of resistance to the Mexican bean weevil in dry beans. J. Econ. Entomol. 75, 567-569.

Schoonhoven, A., Cardona, C. van, Valor, J., 1983. Resistance to the bean weevil and the Mexican bean weevil (Coleoptera; Bruchidae) in non cultivated common bean accessions. J. Econ. Entomol. 76, 1255-1259.

Simmonds, M.S.J., 2001. Importance of flavonoids in insect-plant interactions: feeding and oviposition. Phytochemistry 56, 245-252.

Simmonds, M.S.J., 2003. Flavonoid insect-interactions: recent advances in our knowledge. Phytochemistry 64, 21-30.

Smith, C.M., 2005. Antibiosis: adverse effects of resistance on arthropod biology plant resistance to arthropods. In: Smith, C.M. (Ed.), Plant Resistance to Arthropods. Springer, Dordrecht, pp. 65-94.

Souza, B.H.S., 2014. Fatores e Mecanismos que Influenciam a Resistência em Soja a Anticarsia gemmatalis Hübner E Spodoptera frugiperda (J. E. Smith). 147 f. Tese (Doutorado em Agronomia). Faculdade de Ciências Agrárias e Veterinárias Universidade Estadual Paulista, Jaboticabal.

Statsoft, Inc, 2004. Statistica (Data Analyses Software System), Version 7.

Suzuki, K., Ishimoto, M., Kikuchi, F., Kitamura, K., 1993. Growth inhibitory effect of an $\alpha$-amylase inhibitor from the wild common bean resistant to the Mexican bean weevil (Zabrotes subfasciatus). Jpn. J. Breed. 43, 257-265.

Taiz, L., Zeiger, E., 2009. Fisiologia Vegetal, fourth ed. Artmed, Porto Alegre. 819 pp. Vieira, C., Borém, A., Ramalho, M.A.P., Carneiro, J.E.S., 2005. Melhoramento do Feijão. In: Borém, A. (Ed.), Melhoramento de Espécies Cultivadas. UFV, Viçosa, pp. 301-391.

Wanderley, V.S., Oliveira, J.V., Andrade Jr., M.L., 1997. Resistência de cultivares e linhagens de Phaseolus vulgaris L. a Zabrotes subfasciatus (Boh.) (Coleoptera: Bruchidae). An. Soc. Entomol. Bras. 26, 315-320. 